\title{
Factors Influence Internal Audit Effectiveness
}

\author{
Dhiaa Shamki ${ }^{1} \&$ Thuraiya Amur Alhajri ${ }^{2}$ \\ ${ }^{1}$ Al Zahra College for Women, Muscat, The Sultanate of Oman \\ ${ }^{2}$ Public Authority for Social Insurance, Muscat, The Sultanate of Oman \\ Correspondence: Dhiaa Shamki, Al Zahra College for Women, Muscat, The Sultanate of Oman. E-mail: \\ dhiaa@zcw.edu.om
}

Received: July 26, 2017

doi:10.5539/ijbm.v12n10p143

\author{
Accepted: September 10, 2017 Online Published: September 17, 2017 \\ URL: https://doi.org/10.5539/ijbm.v12n10p143
}

\begin{abstract}
This study aims to examine to what extent internal audit effectiveness could be influenced by selected factors namely internal audit scope, internal auditor's experience and senior management's response in the Omani public sector. Employing questionnaire including four sections with 48 questions for responds of 45 managers and 163 employees in Public Authority for Social Insurance (PASI) in the Sultanate of Oman, descriptive analysis, correlation analysis, and multiple regressions were employed to examine the relationships among the study's variables. The study found that a significant relationship between internal audit effectiveness and its scope and auditors' experience in the employees' sample while they were insignificant in the managers' sample. Finally, it is found that there is insignificant relationship between internal audit effectiveness and senior management's response. Based on the findings, an awareness has to be maximized on employees to better cooperate with internal audit staff to improve the applications of internal audit standards. Managers are well interested in organization's activities and performance depending on the internal audit findings and observations. The board of directors has to take in its considerations the reasons of these insignificant results if the reasons are not related to the small size of the managers' sample. The study's contribution is to provide evidence regarding the influence of three mentioned factors on the internal audit effectiveness in public sector.
\end{abstract}

Keywords: Internal audit scope, internal auditors' experience, management response, internal audit effectiveness, PASI, the Sultanate of Oman

\section{Introduction}

As long as changes occurred in business environment, management has to play a big role in managing their institutions and be more effective in applying its laws. Failing to do so, great scandals of financial embezzlements, frauds and losses might face the world's largest companies and institutions in various sectors.

Internal audit processes provide a reasonable but not absolute assurance for the performance of the whole organization as well as its departments. At different management levels and for the purpose of giving guidance and advice, organizations have shown an increased concern to their internal auditors (Davies, 2001). Internal audit efficiency and effectiveness in handling and achieving the established objectives could be described within a similar concept. Periodically, internal audit efficiency and effectiveness have to be evaluated as a part of the internal audit process (Dubis et al., 2010).

The internal auditing scope is to examine and evaluate to what extent have the organization's governance and risk management are adequate and effective.

Internal audit along with internal control systems ensure the integrity procedures, but when some irregularities float up, recommendations report has to be sent to the board of directors who takes the appropriate solutions to close observation. Sometimes managers are procrastinating in implementing the recommendations and closing remarks for many reasons (Hayes et al., 2014).

It is unclear for this paper whether the internal audit findings and observations could correct or reduce organizational function errors and we expect that some managers will not respond to the internal audit findings.

No evidence has been found related to Omani public sector that examines the influence of the internal audit scope and internal auditor's experience and senior management's response on the internal audit effectiveness. We aimed to find to what extent our results in Omani public sector is consistent to the global ones. To ensure that 
internal audit findings are efficient enough to reduce errors and improve organization work, we decided to condense our efforts in this area of research to well indicate the internal audit findings roll on improving organization work.

In Public Authority for Social Insurance (hereafter PASI) as a public sector in the Sultanate of Oman, there is a lack in; (i) internal auditors who are working regarding auditing scope; (ii) experienced auditing staff; and (iii) senior management's response. This study is built to examine whether or not these factors influence the internal audit effectiveness.

The study addresses whether internal audit scope, internal auditors' experience and senior management's response influence the internal audit effectiveness. Our study's objectives are to examine the influence of the mentioned factors on the internal audit effectiveness. Our study differs from others in; (i) providing empirical evidence regarding the influence of management response on the internal audit effectiveness which has not been well researched before in public sector organizations as referred by Badara and Saidin (2013); (ii) presenting an argument on the influence of the mentioned factors on the internal audit effectiveness based on two respondents' samples; and (iii) being the first that examines this influence in a public sector in the Sultanate of Oman.

To fill the gap in this area of literature in the Sultanate of Oman, our study provides an important evidence regarding the influence of mentioned factors on the effectiveness of internal audit. Our results present the role of these factor in improving and enhancing the internal audit performance.

Our study continues as follows: Section two builds the research framework after reviewing the topic literature. Information about PASI is presented in section three. Our research hypotheses and methods are presented in section four. Section five implies our findings. Findings discussion, conclusions and contributions are presented in last section.

\section{Literature Review}

\subsection{Internal Audit Effectiveness}

Internal audit occupies a unique position in the internal assurance services given by the public and regulatory bodies pushed by the current organizations scandals and global financial crisis (Soh and Bennie, 2011). Issues related to auditing and financial prevision and reporting have been unfolded since financial markets crisis on 2007. To evaluate businesses, management has to evaluate both employees' honesty and work's efficiency. These responsibilities have been delegated to the established formal internal audit function (Ramamoorti, 2003).

\subsection{Internal Audit Effectiveness and Scope}

Quickly, internal audit scope has been extended to include most of financial transactions' verification, and gradually moved from auditing for management to auditing of management approach (Reeve, 1986). IIA (2010) defined internal audit effectiveness as the degree to which establish objectives are achieved.

Internal auditing could assist organizations in better accomplish their objectives by fetching a systematic and disciplined approach to improve and evaluate the control, risk management, and the governance processes effectiveness (IIA, 2009).

The internal auditors have to be characterized with the highest professional objectivity levels of communicating skills including gathering and evaluating information related to the examined activities or processes (IIA, 2009).

While management's increased attention to internal audit recommendations encouraged internal auditors to provide their best efforts, the lack of management attention gives the auditee a bad idea regarding the importance of internal auditing which in turn adversely affect the auditee attributions (Mihret and Yismaw, 2007).

A survey on internal auditors has been conducted by Van Peursem (2004) in New Zealand to specify the functions that internal auditors believe to be necessary to their role. This survey tried to explain the internal auditors' role dilemma which arise from the expectation that internal auditors could assist the management as well as independently evaluate it. Many respondents refer to that in the recent years the internal audit's role has been changed from a policeman' to a consultant.

\subsection{Internal Audit Effectiveness and Auditors' Experience}

The IIA's standard 1210 refers to that auditor's proficiency requires the internal auditors to be with high skills, knowledge and other competencies to better perform their responsibilities (IIA, 2011). Auditing general experience is related to audit's years of experience, training, knowledge, skills and expertise that can be applied to any client (Wright and Wright 1997).

Prawittet et al. (2008) showed that while experience should be reflected by the average number of internal 
auditing experience years that the internal auditors have spent in internal audit function, it cannot be a function for job's years. Instead, experience is related to the suitable training environment that could provide a practice with feedback (Carpenter et al., 2002).

Many studies indicate that gaining such experience means that auditors know more about errors, occasional errors, their cause and the ways that provide more specific knowledge about them (Intakhan \& Ussahawanitchakit, 2010; Gaballa \& Ning, 2011).

Moyes (2007) shows that highly experienced auditors perform more effectively than other with less experience because experienced auditor have the ability to process information, make successful comparisons about the alternative solutions for auditing findings and initiate subsequent actions (Chung \& Monroe, 2000).

Auditing experience is strongly associated to the different levels of knowledge and skills that the auditor has acquired as a result of long job practice in auditing professions in a way that can enhance his effectiveness (Badara \& Saidin, 2013).

Bonner and Lewis (1990) referred to that auditor's experience is a remarkable predictor for knowledge but persons couldn't equally have acquired all types of knowledge. Likewise, persons with similar level of experience in a domain do not have the same abilities in solving problems. This is because solving a problem is highly depended on the task nature or auditees activities where different types of knowledge are gained from different specific experiences and training.

Carpenter et al. (2002) indicated that while having audit experience does not give auditor the capacity to detect frauds, having individual experiences in detecting fraud fits him with the ability of fraud detection. Therefore, diversifying in audit knowledge provides a strong fundamental to audit efficiency and effectiveness (Musig and Ussahawanitchakit, 2011).

Knowledge in public sector organizations occupies a very important role in internal auditing where many studies show that a specific task experience could improve auditors' abilities and auditing as a profession largely rely on the judgments of well-trained experts (Wright \& Wright, 1997; Chung \& Monroe, 2000; Carpenter et al., 2002).

When evaluating organization's internal control, external auditors rely on internal auditors' results illustrating their effective role in evaluating and improving that organization internal control system. It is concluded that internal auditors have more effective role if they are working in a strong business risk environment and having a strong relationship with the audit committee. With high quality findings of internal audit, the internal audit function will be highly effective (Munro \& Stewart, 2011).

Therefore, expert auditors have to be sure that their judgments in any issue must always be accurate enough to keep on going along with the standards. Bierstaker and Thibodeau (2006) indicated that auditors with high level of experience could acquire and consider the relevant information better than those with less experience because the former has the ability to utilize more concepts in their memory in a way that leads them to acquire more relevant information.

Audit experience has been considered by Musig and Ussahawanitchakit (2011) as the skills that the auditors gained when auditing the tasks by applying relevant audit standards, accounting guidance and then their error specific experiences (i.e. financial misstatements).

Chi et al. (2010) conducted that researchers are fully agreed with that the financial statements could be more confident when they been audited and signed by highly experienced auditors. Carpenter et al. (2002) and Asare et al. (2009) supported this issue referring to that for many years accounting has been attacked due to auditors' inability in detecting frauds before the disclosure of a company's financial statements because they ignore the standards requirements and unfortunately let their clients to dictate their reporting choices.

Furthermore, highly experienced auditors have aware more about the influence of the regulations on auditing process which in turn improves their auditing quality more than the inexperience ones (Gaballa \& Ning, 2011).

This might be due to that the knowledge structure could affect their auditing functions, duties in addition to their audit activities (Intakhan \& Ussahawanitchakit, 2010). Therefore, auditing experience plays a major role in auditing effectiveness especially in the public sector organizations. This issue is so important on account of that when small local offices produce a lower quality it will significantly damage the entire firm's reputation.

In the governmental sectors, internal audit function has been found to be of less effectiveness for many reasons such as lack of auditing staff and auditee cooperation or insufficient experience, training, and independence (Ahmad et al., 2009).

Arena and Azzone (2009) study demonstrated that internal audit effectiveness could be increased by increasing 
the ratio between the number of skilled internal auditors to other employees.

As audit experience plays an independent role, its relationship with audit effectiveness has not been well researched especially in the public sector organizations (Badara and Saidin, 2013).

While auditor's experience represents one of the major topics in the area of auditing research (Intakhan \& Ussahawanitchakit, 2010) and one of the internal audit's critical dimensions is internal auditor's experiences and skills (Seol et al, 2011), there is a need for the current study as well as the future ones to expand the research on audit staff experience.

Highly experienced auditors have been usually tasked to evaluate and control various tasks within the audit firms (Arel et al., 2005). Accordingly, managements turn their attention towards judgments of the highly experienced group than those of the lower experienced group (Kaplan et al., 2008). This will be discussed in next section.

\subsection{Internal Audit Effectiveness and Management's Response}

Recently, management relies on internal audit to ensure; organizations' confidence, trust in their effective internal controls and the whole organization is working efficiently (Mahzan et al., 2012).

Since internal auditors display their findings as observations and recommendations, managements play an essential role in implementing good controls in terms of determining the controls' needs; designing appropriate controls; implementing them; checking the correct application; and maintaining and updating the control systems (Pickett, 2011).

While creating internal control systems is managements' responsibility, internal auditors' responsibility is making an objective assessment for those systems (Lin Ct et al., 2009).

As internal auditors pay more attention about what is useful to assess risks and undertake efficient control, their recommendations could assist management in strengthening internal control systems (Badara and Saidin, 2013).

Practically managements have a tangible influence on the internal audit department. This causes difficulties to float out for the reasons of the influence of managers' positions, the power in audit appointment and the need to assume managers' honesty. Therefore, risks will arise when those managers might override the internal control by dealing with it as a managerial tool (Churyk et al., 2008).

In other words, internal auditors have to keep away from (i) setting risk appetite; (ii) imposing risk management processes; (iii) being the core for the assurance of management in such a way to ensure that risks will be effectively managed; (iiiv) taking decisions regarding risk responses; and (v) carrying out risk responses on behalf of the management because they are management's responsibilities not internal auditors ones (Zwaan et al., 2009).

However, Mahzan et al. (2012) stated that internal auditors can effectively perform their roles if they act independently and not as a managerial tool and management is more likely to comply with internal auditors' recommendations if there is authority.

audit's independency is defined as that audit function which is free from any conditions that can threaten the internal audit function ability to implement its responsibilities in an unbiased way and being free from any interferences within setting its scope, performing work and communicating the results (IIA, 2009).

Limited studies have examined the influence of senior management on internal audit objectivity (Stewart \& Subramaniam, 2010). Van Peursem (2004) found out that the internal auditors are highly associated with the management which in turn can threaten their independency. Sarens and de Beelde (2006) examined this association for five Belgian companies and they found a lack in objectivity and weak association with auditing committee when internal auditors operate in managements support role.

Internal auditors could assist management via their consulting role which support the organization to better evaluate, identify, and implement the methodologies of risk management to be able to well address those risks (Badara \& Saidin, 2013).

An effective manager could be defined as that one who cannot feel afraid of internal auditor when identifying issues in the operations. Badara and Saidin, (2013) state that instead managers have to encourage their internal auditor by a proactive policy and do not worry about whether or not the issue will be reported. What is important is to show that actions have already been taken after the issue was found.

Kaplan et al. (2008) noted that auditors' judgments could be influenced by the management if the information provided serves management's self-interest, if not that information will be viewed with less suspicion.

James (2003) has investigated bank lending officers' perceptions regarding the influence of reporting structure on 
internal auditors' abilities in avoiding the financial statements fraud. He states that the reports raised to the senior management seem as having less ability to prevent fraudulent reporting in comparison with those directly reported to the audit committee.

According to Hailemariam (2014), the lack in literature regarding management response to the internal audit findings in the public sector has to be taken in consideration and there is a need to extend this area of research. This motivates this study to examine whether management responds to internal audit findings and implement the submitted recommendations.

\subsection{Theoretical Framework}

The relationship between the internal auditors and the management is based on the interests' conflict. This conflict depends on another interest conflict between the management and the board of directors. Both conflicts are explained by the agency theory. This theory assumes that there is a conflict of interests between two parties. The first is the principal and the second is the agent. They are linked by a contract whereby the principal (the manager in the case of audit and directors board in the case of the organization) hires the second party's efforts (internal auditor in the case of audit and the manager in case of organization) to perform tasks for the benefit of principal and on his behalf (Jensen \& Meckling, 1976). In both contracts, each party tries to achieve his own interests.

As managers use what they know about organization's affairs to promote their interests, they try to spruce up their performance that is evaluated by the board of directors. Therefore, managers exert pressure on internal auditors in order to tilt them to show results that supports the management. This caused information asymmetry that could badly affect firm's value and arise agency problem (Holthausen \& Watts, 2001).

Agency theory indicates that agency problems might arise due to incomplete information and uncertainty conditions (Eisenhardt, 1989). Information asymmetry (if exists) can play an effective role in the misunderstanding between managers and other interested parties affecting firms' performance and value (Weil, 2002). When internal audit accomplishes its goals, brings a disciplined and systematic approach to well improve and evaluate risk management's effectiveness, control and governance processes. This could enhance firm's performance and maximize its value. The relationships among internal audit effectiveness as a dependent variable and internal audit scope, internal auditors' experience and management response as independent variables are diagramed into a framework as in Figure 1.

\section{Independent Variables}

\section{Dependent variable}

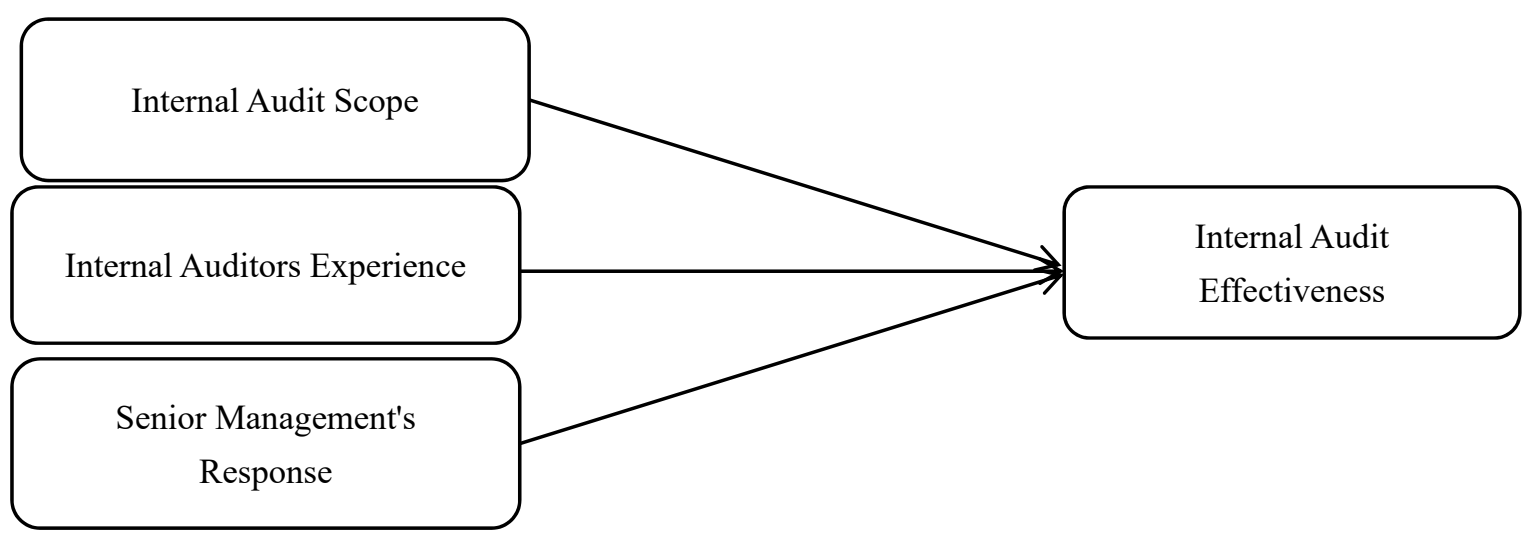

Figure 1. Conceptual framework

\section{Public Authority for Social Insurance (PASI)}

PASI is chosen to be our population. The Social Insurance Law that have been promulgated by the Royal Decree No.72/91, came into force since the first of July 1992. Omani economic growth within the period from 1992 to 2015 increases insured person employees, active employers and spent cases (OR) numbers from 1679, 814 and 120,402 to $209,620,15,471$ and $58,644,000$ respectively. PASI receives the contributions' payments regarding to all benefits that are covered by the mentioned law.

To increase returns and distribute risks, PASI follows a wise plan in investing the collected funds locally and externally within specified proportions. For the period from 2011 to 2015, total assets are increased from OR $668,770,000$ to $1,133,474$ and investment assets from OR $647,676,000$ to $999,737,000$ (PASI annual reports, 
2011-2015).

The increase in PASI insured employees, active employers and spent cases numbers will face an increase in the expenses and income amounts. In the Sultanate of Oman and among nine selected ministries, eight authorities and three organizations in the public sector, PASI has been ranked the first in income while its expenses amounts ranked the fifth in 2014 and the forth in 2015 (Ministry of Finance - Oman, 2015).

As internal audit departments follow a systematic method to improve and evaluate the control, risk management effectiveness, and governance processes, PASI 2015 annual report shows that sectors of Insurance, administrative and finance, investment and other have only 12 internal auditors for a total of 368 employee referring to insufficient auditors to audit the PASI employees' tasks, departments and offices. Therefore we are stimulated to select PASI as the source of sample data.

\section{Hypotheses Development and Research Methods}

Based on the theoretical framework and in accordance with the study's problem, questions and objectives, the research hypotheses are stated as:

H1: Internal audit scope influences internal audit effectiveness.

$\mathrm{H} 2$ : internal auditor's experience influences internal audit effectiveness.

H3: Senior management's response influences internal audit effectiveness.

we examine the influence of three independent variables (hereafter IVs) namely internal audit scope, internal auditors' experience and management response on one dependent variable (hereafter DV) namely, the internal audit effectiveness. Our strategy is collecting data via questionnaire and archival data of PASI. As our study is a qualitative one, questionnaires are more appropriate for obtaining quantitative information of how many people hold a certain opinion (Kitzinger, 1995).

A stratified random sampling for a representative sample from different sectors (insurance, finance and management, investments and others) and different positions (employees and senior managers) is found relevant to be adopted in the study.

Our targeted sample covered all sectors in PASI and its population's frequencies and percentages are summarized in Table 1. Our sample includes 163 employees and 45 managers out of 290 and 78 in population respectively.

This analysis enables the study to capture the incremental effects of audit scope, auditors' experience and management response on internal audit effectiveness under three hypotheses

For employees' sample, our regression model is:

$$
I A E=\beta 0+\beta_{1} S C O P E+\beta_{2} \text { EXPERIENCE }+e
$$

where; IAE $=$ internal audit effectiveness; $\mathrm{SCOPE}=$ audit scope; Experience $=$ internal auditor's experience; $\mathrm{e}=$ errors term.

For managers' sample, our regression model is:

$$
I A E=\beta O+\beta_{1} S C O P E+\beta_{2} \text { EXPERIENCE }+\beta_{3} \text { MANAGRESP }+e
$$

where; MANAGRESP $=$ senior managers' response; other variables are defined before.

From the constructed regression equations for the study, the standardized coefficients (Betas values) illustrate the contribution of each IVs in explaining and reflecting the variance in the DV. The t-test and the associated 2-tailed p-values are used in testing whether a given coefficient is significantly different from zero (Pallant, 2010).

\section{Findings}

The important major assumptions that must be taken in the researchers' consideration are normality, correlation, linearity, multicollinearity, and homoscedasticity. Testing these assumptions makes the data being suitable for regression analysis (Pallant, 2010; Jones Jr, 2010).

Our sample in total is 208 respondents from PASI (163 employees and 45 managers) formed 78.4 and 21.6 percent respectively. Regarding employees sample descriptive statistics shown in Table 1, each factor of gender, age, education, experience, or sector has 163 observations. Among these factors, experience recorded the highest mean and median values while the lowest are for gender. All factors' standard deviation values are below 3 which ensure the absence of outliers that could significantly affected the analysis and in turn the results. Most factors present skewness and kurtosis values within \pm 2 which ensures the normal distribution of our variables. Table 1 shows no violation from regression assumptions that might affect study's both analysis and results. 
Table 1. Descriptive statistics for employees' sample

\begin{tabular}{llllll}
\hline & Gender & Age & Education & Experience & \multicolumn{1}{l}{ Sector } \\
\hline $\mathrm{N} \quad$ Valid & 163 & 163 & 163 & 163 & 163 \\
\multicolumn{1}{c}{ Missing } & 0 & 0 & 0 & 0 & 0 \\
Mean & 1.4110 & 1.6503 & 2.1963 & 2.2638 & 1.6871 \\
Median & 1.0000 & 2.0000 & 2.0000 & 2.0000 & 1.0000 \\
Std. Deviation & .49354 & .70740 & 1.83202 & 1.16443 & .91302 \\
Skewness & .365 & .830 & 8.012 & .634 & 1.304 \\
Std. Error of Skewness & .190 & .190 & .190 & .190 & .190 \\
Kurtosis & -1.890 & .240 & 84.778 & -.445 & .860 \\
Std. Error of Kurtosis & .378 & .378 & .378 & .378 & .378 \\
Minimum & 1.00 & 1.00 & 1.00 & 1.00 & 1.00 \\
Maximum & 2.00 & 4.00 & 6.00 & 6.00 & 4.00 \\
\hline
\end{tabular}

Regarding descriptive statistics for managers' sample shown in Table 2, each mentioned factor has 45 observations. Among these factors, the experience recorded the highest mean and median values while the lowest are for gender factor. Standard deviation values are less than 3 which ensure the absence of outliers. All factors show skewness and kurtosis values that are within \pm 2 which ensure the normal distribution. Table 2 shows that no violation from regression assumptions.

Table 2. Descriptive statistics for managers' sample

\begin{tabular}{|c|c|c|c|c|c|c|}
\hline & & Gender & Age & Education & Experience & Sector \\
\hline \multirow[t]{2}{*}{$\mathrm{N}$} & Valid & 45 & 45 & 45 & 45 & 45 \\
\hline & Missing & 0 & 0 & 0 & 0 & 0 \\
\hline \multicolumn{2}{|c|}{ Mean } & 1.1818 & 2.2727 & 2.8182 & 3.5682 & 1.8182 \\
\hline \multicolumn{2}{|c|}{ Median } & 1.0000 & 2.0000 & 2.5000 & 4.0000 & 1.0000 \\
\hline \multicolumn{2}{|c|}{ Std. Deviation } & .39015 & .75832 & 1.12628 & 1.28312 & 1.16684 \\
\hline \multicolumn{2}{|c|}{ Variance } & .152 & .575 & 1.268 & 1.646 & 1.362 \\
\hline \multicolumn{2}{|c|}{ Skewness } & 1.709 & -.175 & .989 & -.435 & 1.107 \\
\hline \multicolumn{2}{|c|}{ Std. Error of Skewness } & .357 & .357 & .357 & .357 & .357 \\
\hline \multicolumn{2}{|c|}{ Kurtosis } & .961 & -.623 & 1.022 & -.212 & -.382 \\
\hline \multicolumn{2}{|c|}{ Std. Error of Kurtosis } & .702 & .702 & .702 & .702 & .702 \\
\hline \multicolumn{2}{|c|}{ Minimum } & 1.00 & 1.00 & 1.00 & 1.00 & 1.00 \\
\hline
\end{tabular}

\subsection{Correlation Test}

Results from Table 3 show a weak and a very weak relationships between internal audit scope and internal auditors' experience with internal audit effectiveness for managers' sample.

For employees' sample, Table 4 shows significant correlations between audit scope and experience with internal audit effectiveness. 
Table 3. Correlation test between Internal audit effectiveness, Audit scope, Experience and Management response for managers' sample

\begin{tabular}{llllll}
\hline Internal & Audit & Pearson Correlation & 1 & & \\
Effectiveness & Sig. (2-tailed) & & & \\
Scope & $\mathrm{N}$ & 45 & & \\
& Pearson Correlation & .067 & 1 & \\
& Sig. (2-tailed) & .665 & & & \\
Experience & $\mathrm{N}$ & 45 & 45 & & \\
& Pearson Correlation & -.204 & .088 & 45 & \\
& Sig. (2-tailed) & .184 & .570 & .090 & 1 \\
Management & $\mathrm{N}$ & 45 & 45 & .563 & \\
response & Pearson Correlation & -.046 & $.357^{*}$ & .017 & 45 \\
& Sig. (2-tailed) & .765 & .017 & \\
\hline
\end{tabular}

* Correlation is significant at 0.05 level or better.

Table 4. Correlation test between Internal audit effectiveness, Audit scope, Experience and Management response for employees' sample

\begin{tabular}{lllll}
\hline Internal Audit & Pearson Correlation & 1 & & \\
\cline { 2 - 4 } Effectiveness & Sig. (2-tailed) & & & \\
\multirow{5}{*}{ Scope } & $\mathrm{N}$ & 163 & & \\
& Pearson Correlation & $.357^{* *}$ & 1 & 1 \\
\multirow{5}{*}{ Experience } & Sig. (2-tailed) & .000 & & \\
& $\mathrm{~N}$ & 163 & 163 & 163 \\
& Pearson Correlation & $.419^{* *}$ & $.282^{* *}$ & \\
\multirow{4}{*}{$* *$ Correlation is significant at 0.01 level (2-tailed). } & .000 & .000 & \\
\hline
\end{tabular}

\subsection{Regression Results for Employees'Sample}

Hypotheses 1 and 2 state that internal audit scope and its internal auditor's experience influence the internal audit effectiveness, while Hypothesis 3 states that the senior management's response influences the internal audit effectiveness. The significant $F$ statistic shown in Table 5 indicates that the model as a whole is significant to be adopted for employees' sample but not for managers' sample.

Table 5. Comparison between the regression results

\begin{tabular}{llll}
\hline & & \multicolumn{2}{l}{ Results of the sample of } \\
Model / variable & Coefficients & Employees & Managers \\
\hline & R & .488 & .230 \\
& R Square & .238 & .053 \\
& Adjusted R Square & .228 & -.018 \\
& F & 24.949 & .744 \\
& Sig. & .000 & .533 \\
\hline & Beta & .259 & .109 \\
Audit & t-test & 3.607 & .661 \\
Scope & Sig. & .000 & .512 \\
\hline & Beta & .346 & -.208 \\
Staff & t-test & 4.811 & -1.342 \\
Experience & Sig. & .000 & .187 \\
\hline & Beta & & -.067 \\
Management & t-test & /// & -.404 \\
Response & Sig. & & .688 \\
\hline
\end{tabular}


For employees' sample results, it is clear that audit scope has significantly and positively influenced the internal audit effectiveness $(\beta=0.259$ and t-test $=3.607$ at $\mathrm{P}=0.00)$. Auditors' experience has significantly and positively influenced the internal audit effectiveness $(\beta=0.346$ and t-test $=4.811$ at $\mathrm{P}=0.00)$.

Managers' sample results show insignificant association for audit scope, auditors' experience and senior management's response with internal audit effectiveness reflected by the betas coefficients and t-test $(\beta=0.109$ and t-test $=0.661),(\beta=-0.208$ and t-test $=-1.342)$ and $(\beta=-0.067$ and $t$-test $=-0.404)$ for audit scope, auditors' experience and senior management's response respectively.

\section{Discussion, Conclusions and Contributions}

\subsection{Discussion}

\subsubsection{Internal Audit Effectiveness and Audit Scope}

Regarding Hypothesis (1), the result of employees' sample is consistent with many studies (Van Peursem, 2004; Mihret and Yismaw, 2007; Intakhan and Ussahawanitchakit, 2010) and supported by IIA (1999) internal audit definition, and Moeller (2009) who associates internal audit effectiveness with the significant business activities, developments, voluminous and diverse transactions' results. Hypotheses (1) is accepted for employees' sample but not for managers one. As our findings revealed that internal audit scope has positively influenced internal audit effectiveness in employees' sample but not in managers' sample.

\subsubsection{Internal Audit Effectiveness and Its Auditors' Experience}

From testing Hypothesis (2), the result of employees' sample is supported by the IIA's standard 1210. This standard mentioned to that the internal auditors should possess the knowledge, skills and other competencies that they have need to perform their responsibilities (IIA, 2011). Also, our result is harmonious with many previous studies that considered the knowledge to be having a very important role in internal auditing in the public sector organizations and specific task experience can improve auditors' judgments (Carpenter et al., 2002; Chung and Monroe, 2000).

For the positive and significant relationship between internal audit effectiveness and auditors' experience, our result is conformable with studies that considered auditors as have to utilize their experience in order to achieve effectiveness (Intakhan and Ussahawanitchakit, 2010) and the impact of experience in decision making aspect (Wright and Wright, 1997).

Since it is found that highly experienced auditors perform more effectively than less experienced ones (Bonner and Lewis, 1990), experienced auditors are more able to use their knowledge in sophisticated ways than inexperienced auditors (Choo and Trotman, 1991), and the more relevant information is acquired and considered by more experienced auditors than less experienced ones (Bierstaker and Thibodeau, 2006).

Our result is consistent with studies that define knowledge as the years of audit experience (Wright and Wright, 1997; Prawittet et al., 2008) or the proper training environment as well as years of audit experience (Carpenter et al., 2002),

This result is supported by IIA (1999) internal audit definition and the studies of (Moeller, 2009) who associates internal audit effectiveness with significant business activities, developments, voluminous, diverse transactions' results and auditable activities number or units in different business units. Hypotheses (2) has been accepted for employees' sample but not for managers' sample as our findings revealed that auditors' experience has positively influenced the internal audit effectiveness in the employees' sample but not in the managers' one.

\subsubsection{Internal Audit Effectiveness and Management's Response}

Results from testing Hypothesis (3) are consistent with previous studies of Sarens and de Beelde (2006) who found that internal auditors have weakly associated with the audit committee when they operate with managements support role and lack the perceived objectivity; Churyk et al. (2008) who indicates that managers might override internal control considering it as a managerial tool; and Stewart and Subramaniam (2010) who concluded that limitedly, the senior management influenced internal audit objectivity.

This result is inconsistent with the studies of Churyk et al. (2008) who found a big influence of management on internal audit department, and Badara and Saidin, (2013) who found that internal audit supplies management with a real assurance that they have adequate controls and any failures will be investigated and directly remedied. Hypotheses (3) has been rejected as our findings revealed that management response has insignificant influence on the internal audit effectiveness. 


\subsection{Contributions}

As the study's results are insignificant for managers' sample, the board of directors has to take in its considerations the reasons of these insignificant results if the reasons are not related to the small size of the managers' sample. In the other side, as employees' sample shows significant positive influence, awareness has to be maximized on employees to better cooperate with internal audit staff to improve the applications of internal audit. Therefore, board of directors, controls and public accountants might be interested with the trend of the findings. Employing data from the Sultanate of Oman in the study contributes to enrich literature in this area of research. Concluding similar results to that from prior research that employed data from different regions in the world could strengthen and generalized the results. Since audit in general and internal audit in practical are essential components for accounting courses, the results are relevant for the courses theoretically and practically.

\subsection{Limitations of the Study}

The unexpected results for managers' sample might be; because Omani senior managers focus more on findings of other audit parties than on that of internal audit department; due to the specific characteristics of Omani public sector environment; related to the small sample size of the managers' sample or period; related to the characteristics of the PASI where its services are provided to many people who need quick procedures. The mentioned limitations will not underestimate study's value and its importance and usefulness are not questionable.

\subsection{Suggestions for Future Research}

Future studies are called to extend this study by examining the influence of other factors on the internal audit effectiveness. This may provide new insights of the possible factors that could influence this effectiveness. Future research is encouraged to employ larger sample size to investigate whether this factor may moderate its influence on the internal audit effectiveness. Future studies also are called to examine the influence of many factors on internal audit effectiveness and compare the results with others from across countries in Middle East, Gulf Cooperation Council, or with other regions which could generalize the results of the internal audit effectiveness.

\section{References}

Ahmad, H., Othman, R., \& Jusoff, K. (2009). The Effectiveness of Internal Audit in Malaysian Public Sector. Journal of Modern Accounting and Auditing, 5(9), 53-62. Retrieved from http://www.ssrn.com/abstract=2162236

Arel, B., Kaplan, S. E., \& Donnell, E. O. (2005). Evaluating internal controls: The moderating effect of auditor experience on the persuasiveness of evidence from management self-assessment. Retrieved from http://citeseerx.ist.psu.edu/viewdoc/summary?doi=10.1.1.511.6429

Arena, M., \& Azzone, G. (2009). Identifying organizational drivers of internal audit effectiveness. International Journal of Auditing, 13, 43-60. http://dx.doi.org/10.1111/j.1099-1123.2008.00392

Asare, S. K., Cianci, A. M., \& Tsakumis, G. T. (2009). The impact of competing goals, experience, and litigation consciousness on auditors' judgments. International Journal of Auditing, 13, 223-236. http://dx.doi.org/10.1111/j.1099-1123.2009.00389

Badara, M., \& Saidin, S. (2013). The relationship between audit experience and internal audit effectiveness in the public sector organizations. International Journal of Academic Research in Accounting, Finance and Management Sciences, 3(3), 329-339. http://dx.doi.org/10.6007/IJARAFMS/v3-i3/224

Bierstaker, J. L., \& Thibodeau, J. C. (2006). The effect of format and experience on internal control evaluation. Managerial Auditing Journal, 21(9), 877-891. http://dx.doi.org/10.1108/02686900610704984

Bonner, E., \& Lewis, B.L. (1990). Determinants of auditor expertise. Journal of Accounting Research, 28, 1-20. http://dx.doi.org/10.2307/2491243

Carpenter, T., Durtschi, C., \& Gaynor, L. M. (2002). The role of experience in professional skepticism, knowledge acquisition, and fraud detection. Retrieved from http://www.ssrn.comon

Chi, W., Myers, L. A., Omer, T. C, \& Xie, H. (2010). The effects of auditors' pre-client and client-specific experience on earnings quality and perceptions of earnings quality: Evidence from private and public $\begin{array}{lllll}\text { companies in } & \text { Taiwan, } & \text { Retrieved } & \text { from }\end{array}$ https://papers.ssrn.com/sol3/Papers.cfm?abstract_id=1304953

Choo, F., \& Trotman, K. T. (1991). The Relationship between knowledge structure and judgments for 
experienced and inexperienced auditors. The Accounting Review, 66(3), 464-485. Retrieved from http://www.jstor.org/stable/247805

Chung, J., \& Monroe, G. S. (2000). The effects of experience and task difficulty on accuracy and confidence assessments of auditors. Accounting and Finance, 40, 135-152. http://dx. doi.org/10.1111/1467-629X.00040

Churyk, N. T., Lee, C. C., \& Clinton, B. D. (2008). Can we detect fraud earlier? Journal of Strategic Finance, 90(4), 51-54.

Davies, M. (2001). The changing face of internal audit in local government. Journal of Finance and Management in Public Services, 1 (2), 15-26. http://dx.doi.org/10.1.1.112.2804

Dubis, G., Jain, P., Manchanda, A., \& Thakkar, R. (2010). Measuring internal audit effectiveness and efficiency: Practice guide. Institute of Internal Auditors (IIA), 1-16.

Eisenhardt, K. M. (1989). Agency theory: An assessment and review. Academy of Management Review, 14, 57-74. Retrieved from https://www.jstor.org/stable/258191

Gaballa, A. S. M., \& Ning, Z. (2011). An analytical study of the effects of experience on the performance of the external auditor. International Conference on Business and Economics Research, 1,169 -173.

Hailemariam, Sh. (2014). Determinants of internal audit effectiveness in the public sector, case study in selected Ethiopian public sector offices. Master Thesis in Accounting and Finance (MSC.) Jimma University, College of Business and Economics.

Hayes, R., Wallage, P., \& Gortemaker, H. (2014). Principles of auditing: An introduction to international standards on auditing. 3rd Edition. Pearson Education Limited.

Holthausen, R., \& Watts, R. (2001). The relevance of the value-relevance literature for financial accounting standard setting. Journal of Accounting and Economics, 31(1-3), 3-75. https://doi.org/10.1016/S0165-4101(01)00029-5

Institute of Internal Auditors (IIA). (1999). Definition of Internal Auditing.

Institute of Internal Auditors (IIA). (2009). Code of Ethics. Standards and guidance. International professional practice framework (IPPF).

Institute of Internal Auditors (IIA). (2010). Measuring internal audit effectiveness and efficiency. IPPF-Practice guide.

Institute of Internal Auditors (IIA). (2011). Practice advisories under international professional practice framework (IPPF).

Intakhan, P., \&Ussahawanitchakit, P. (2010). Roles of audit experience and ethical reasoning in audit professionalism and audit effectiveness through a moderator of stakeholder pressure: An empirical study of tax auditors in Thailand. Journal of Academy of Business and Economics, 10(5), 1-15.

James, K. (2003). The effects of internal audit structure on perceived financial statement fraud prevention. Accounting Horizons, 17(4), 315-327. http://dx. doi.org/10.2308/acch.2003.17.4.315

Jensen, M., \& Meckling, W. (1976). Theory of the firm: Managerial behavior, agency costs and ownership structure. Journal of Financial Economics, 3, 305-360. https://doi.org/10.1016/0304-405X(76)90026-X.

Jones Jr., W. E. (2010). A correlation study of student achievement and student attendance. Ph.D. thesis. School of Education. Capella University.

Kaplan, S. E., Donnell, E. O., \& Arel, B. M. (2008). The influence of auditor experience on the persuasiveness of information provided by management. Auditing: A journal of practice and theory, 27(1), 67-83. http://dx.doi.org/10.2308/aud.2008.27.1.67

Kitzinger, J (1995). Qualitative Research: Introducing focus groups. BMJ, 311, 299-302

Lin, C. T, Chiu, T. T., Huang, T. Y., Chao, C. F., Liang, W. C., Hsu, S. H., \& Ko, L. W. (2009). Assessing effectiveness of various auditory warning signals in maintaining drivers' attention in virtual reality-based driving environments. Percept Mot Skills, 108(3), 825-35. http://dx.doi.org/10.2466/PMS.108.3.825-835

Mahzan, N., Zulkifli, N., \& Umor, S. (2012). Role and authority: An empirical study on internal auditors in Malaysia. Asian Journal of Business and Accounting, 5(2), 69-98. Retrieved from https://umexpert.um.edu.my/file/publication/00001766_90172.pdf

Mihret, D. G., \& Yismaw, A. W. (2007). Internal audit effectiveness: an Ethiopian public sector case study. 
Managerial auditing journal, 22(5), 470-484. https://doi.org/10.1108/02686900710750757

Ministry of Finance-The Sultanate of Oman. (2015). The state General Budget.

Moeller, R. R. (2009). Brink's modern internal auditing: A common body of knowledge (7th ed.). John Wiley and Sons, Inc.

Moyes, G. (2007). The differences in perceived level of fraud - detecting effectiveness of SAS No. 99 red flags between external and internal auditors. Journal of Business and Economics Research, 5(6), 9-26. http://dx.doi.org/10.19030/jber.v5i6.2551

Munroa, L., \& Stewart, J. (2011). External auditors' reliance on internal auditing: Further evidence. Managerial Auditing Journal, 26(6), 464-481. http://dx.doi.org/10.1108/02686901111142530

Musig, P., \& Ussahawanitchakit, P. (2011). Dynamic audit competency and the antecedents and con-sequences: Evidence from tax auditors in Thailand. International Journal of Business Research, 11(3), 47-75.

Pallant, J. (2010). SPSS survival manual (4th ed.). McGraw Hill Education.

Pickett, K. (2011). The Essential Guide to Internal Auditing (2nd ed.). John Wiley and Sons.

Prawitt, D. F., Smith, J. L., \& Wood. D. A. (2008). Internal audit quality and earnings management. Institute of Internal Auditors Research Foundation, 1-42. Retrieved from http://ssrn.com/abstract=916081

Public Authority Social Insurance (PASI) in the Sultanate of Oman. (2011-2015). Annual reports.

Ramamoorti, S., (2003). "Internal auditing: History, evolution, and prospects" in Research Opportunities in Internal Auditing (1st ed.). In Bailey, A.D., A. A. Gramling and S. Ramamoorti, (Eds.), Chapter 1, The Institute of Internal Auditors Research Foundation. Altamonte Springs, FL, 2-23.

Reeve, J. T. (1986). Internal Auditing. In Cashin, J. A., Neuwirth, P. D., and Levy, J. F. (Eds.), Cashin's Handbook for Auditors. Englewood Cliffs, NJ: Prentice Hall.

Sarens, G., \& De Beelde, I. (2006). The relationship between internal audit and senior management: A qualitative analysis of expectations and perceptions. International Journal of Auditing, 10(3), 219-241. http://dx.doi.org/10.1111/j.1099-1123.2006.00351

Seol, I., Sarkis, J., \& Lefley, F. (2011). Factor Structure of the Competency Framework for Internal Auditing (CFIA) skills for entering level internal auditors. International Journal of Auditing, 15(3), 217-230. http://dx.doi.org/ 10.1111/j.1099-1123.2011.00431

Soh., D., \& Bennie, N. (2011). The internal audit function: Perceptions of internal audit roles, effectiveness, and $\begin{array}{llll}\text { evaluation. } & \text { Managerial }\end{array}$ http://dx.doi.org/abs/10.1108/02686901111151332

Stewart, J. and Subramaniam, N. (2010). Internal audit independence and objectivity: emerging research opportunities. Managerial Auditing Journal, 25(4), 328-360. http://dx.doi.org/10.1108/02686901011034162

Van Peursem, K. (2004). Internal auditors' role and authority: New Zealand evidence. Managerial Auditing Journal, 19(3), 378-393. http://dx.doi.org/10.1108/02686900410524382

Weil, D. (2002). The benefits and costs of transparency: A model of disclosure based regulation. Boston University, School of management.

Wright, A., \& Wright, S. (1997). The effect of industry experience on hypothesis generation and audit planning decisions. Retrieve on 1/08/2012 from Social Science Research Network Electronic Paper Collection: Electronic Retrieved from http://papers.ssrn.com/paper.taf?abstract_id=42913

Zwaan, L., Stewart, J., \& Subramaniam, N. (2009). Internal audit involvement in Enterprise Risk Management. Discussion Paper. Griffith University.

\section{Copyrights}

Copyright for this article is retained by the author(s), with first publication rights granted to the journal.

This is an open-access article distributed under the terms and conditions of the Creative Commons Attribution license (http://creativecommons.org/licenses/by/4.0/). 